Bull's Birds of New York State 



\section{BULL'S BIRDS of NEW YORK STATE}

Emanuel Levine, Editor

Berna B. Lincoln and

Stanley R. Lincoln, Associates

$A$ project of the

Federation of New York State Bird Clubs, Inc.

in association with

The American Museum of Natural History

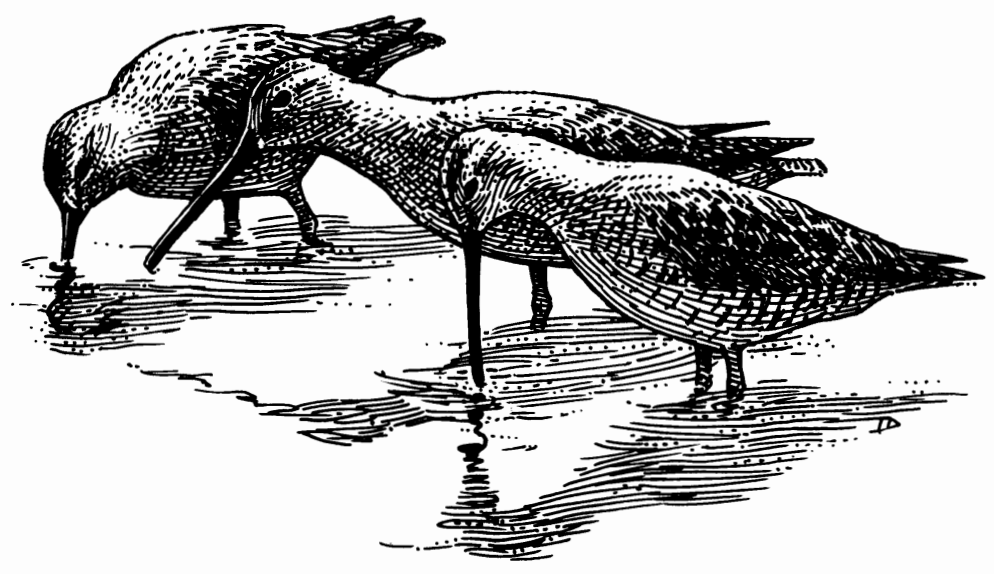

Illustrated by Dale Dyer

Foreword by Governor George E. Pataki

COMSTOCK PUBLISHING ASSOCIATES

A division of Cornell University Press

ITHACA AND LONDON 
The preparation of this publication was funded by the Division of Fish and Wildlife, New York State Department of Environmental Conservation, and the "Return a Gift to Wildlife" program.

Copyright (c) 1998 by the Federation of New York State Bird Clubs, Inc., and the American Museum of Natural History

All rights reserved. Except for brief quotations in a review, this book, or parts thereof, must not be reproduced in any form without permission in writing from the publisher. For information, address Cornell University Press, Sage House, 512 East State Street, Ithaca, New York 14850.

Birds of New York State first published in 1974 by Doubleday/Natural History Press. Reissued 1985 by Cornell University Press, with supplement and corrections. Bull's Birds of New York State published 1998 by Cornell University Press.

\section{LIBRARY OF CONGRESS CATALOGING-IN-PUBLICATION DATA}

Bull, John L.

Bull's birds of New York State / Emanuel Levine, editor; illustrated by Dale Dyer. p. $\quad \mathrm{cm}$.

"A project of the Federation of New York State Bird Clubs, Inc. in association with the American Museum of Natural History."

Rev. ed. of: Birds of New York State. 1985.

Includes bibliographical references and index.

ISBN 0-8014-3404-1 (cloth: alk. paper)

1. Birds-New York (State) I. Levine, Emanuel, 1921- . II. Federation of New York State Bird Clubs. III. American Museum of Natural History. QL684.N7B833 1998

$598^{\prime} .09747-\mathrm{DC} 21$ 